\title{
妄想的観念の主題を測定する尺度の作成'
}

\author{
東京大学 丹野義彦・石垣玩磨 2 杉浦義典
}

\section{Construction of scales to measure thematic tendencies of paranoid ideation}

Yoshihiko Tanno (Department of Life Sciences (Psychology), Graduate School of Arts and Sciences, University of Tokyo, Komaba, Meguro-ku, Tokyo 153-8902), Takuma Ishigaki (Faculty of Education and Human Sciences, Yokohama National University, Tokiwadai, Hodogaya-ku, Yokohama 240-8501) and Yoshinori Sugiura (Research Fellow of Japan Society for the Promotion of Science, Department of Educational Psychology, Graduate School of Education, University of Tokyo, Hongo, Bunkyo-ku, Tokyo 113-0033)

In order to measure thematic tendencies of paranoid ideation in non-clinical samples, Delusional Ideation Checklist (DICL) was developed. A wide range of items indicating themes of delusion were collected. From the results of factor analysis on the data of 308 college students, eight scales were constructed. They were: alienation, belittlement, persecution, other-harming, guardedness, self-conceit, favoredness, and other-manipulation. These scales could be classified in terms of emotion: positive versus negative, and direction: self versus others, and could deal with themes of paranoid ideation in a comprehensive and systematic way. Alpha coefficients of the scales were between .66 and .87 , and test-retest reliability between .49 and .71 . To examine content validity, ten psychiatrists were asked to rate diagnostic importance for each scale item. Six scales were rated as significantly more important in the diagnosis of paranoid schizophrenia than that of anxiety neurosis. Current data revealed that ordinary students experienced delusional ideation more frequently than psychiatrists would expect.

Key words: paranoid ideation, delusions, questionnaire, paranoid schizophrenia.

妄想とは, DSM-IV (American Psychiatric Association, 1994）によると, “外的現実に対する間違った推 論に基づく誤った確信であり，その矛盾を他のほとん どの人が確信しており, 矛盾に対して反論の余地のな い明らかな証明や証拠があるにもかかわらず, 強固に 維持される”ものとされる.この定義は, Jaspers （1948 内村 - 西丸・島崎 - 岡田訳，1953）の古典的 な精神病理学にもとづいている. Jaspers は, 妄想の 特徴として, 主観的に強い確信をもつこと, 経験上こ うであるはずだとかこうだからこうなるという正しい 論理に従わせることができないこと, ありえない内容 であることの 3 点を挙げている。また, Jaspers は, 心理学的に了解しえない“真正妄想” と了解しうる “妄想的観念”に分け, 前者は精神分裂病に特有であ るとした。後者の妄想的観念には，うつ状態や躁状態 の妄想, 健常者にもみられる支配観念などが含まれ る、こうした区別にしたがって，これまでは精神分裂 病の真正妄想と, 精神分裂病以外の妄想的観念は, 質 的に違うものとされ, 非連続性が強調される傾向があ った。しかし，実際には必ずしもこの区別は明確では なく, 精神分裂病においても上の三つの特徴を満たさ

\footnotetext{
1 本研究は文部省科学研究補助金基盤研究 C一般\# 10610068 の補助を受けておこなわれた。

2 現所属：横浜国立大学.
}

ないような中途半端な妄想も多くみられ (Strauss, 1969), 妄想は精神分裂病以外の障害にもきわめて広 く出現し (Manschreck, 1979), また, 被害妄想的な 観念は健常者でも珍しくない（Fenigstein \& Vanable, 1992).このため, こうした区別をせずに，精神分裂 病の妄想から健常者の支配観念までを連続するスぺク トラムとしてとらえる研究者も多い（笠原・藤縄, 1978)。DSM-IVは，妄想と妄想様観念（paranoid ideation）を連続的なものとしてとらえている。妄想 様観念とは“妄想ほどの強さはない観念で, 自分が苦 しめられている, 迫害されている，または不当に扱わ れているという疑念”と定義されている．妄想様観念 の場合，自分が本当にだれかから迫害されているか否 かという観念の客観的正誤はそれほど問題とはなら ず，不当に扱われているのではないかという疑念や苦 痛感情などの主観面が重視されている。本研究におい ては，このようなパラノイア・スペクトラム説の立場 をとり, 真正妄想と妄想様観念とをとりあえず区別せ ず，妄想的観念という語を用いる。

最近は, いくつかの理論的な文脈から妄想に対する 関心が高まっている. 第一は精神分裂病の精神病理学 や治療理論からの関心である。精神分裂病の症状は非 常に複雑であり，Crow（1980）の 2 症候群仮説をき つかけとして，3 症候群説や 5 症候群説なども提出さ れている。その流れのなかで，これまでの疾患中心の 
アプローチにかわり，妄想・幻覚・陰性症状などに分 けて研究する症状別アプローチがさかんとなり (Bentall, 1990), 妄想の心理学的研究も増えている. たとえば，Hemsley \& Garety（1986）は，べイズ理論 にもとづいて信念形成のモデルをたてて，そこからの 逸脱として妄想現象を説明している。また, BrettJones, Garety, \& Hemsley（1987）は, 精神分裂病など の患者を対象として，各患者の妄想の内容を示す文を 提示する PQ 法 (Personal Questionnaire Technique) を用い，その内容についての確信度や心的占有度（1 日どのくらいの時間それを考光るか）など五つの変数 について評定させている。このようなアセスメントを 入院から退院後のフォローアップまで 1 人平均 12 回 おこなった結果, これらの変数は離散的ではなく連続 的に変化しており, これら五つの変数間の相関も低か った.さらに, Sharp, Fear, Williams, Healy, Lowe, Yeadon, \& Holden（1996）は，妄想性障害の患者を 対象として, 認知行動療法をおこない, その効果につ いて MADS (Maudsley Assessment of Delusions Schedule）を用いて調べている. MADS とは，妄想 を七つの下位尺度から評定する面接法である。その結 果, 半数の患者は妄想の確信度が低下した。各下位尺 度間の相関係数は低く, 彼らは妄想が多次元的な現象 であるとしている。また，妄想の認知行動療法 (Chadwick, Birchwood, \& Trower, 1996) など，精神 分裂病の新たな治療介入法が開発されている.

第二は自己意識理論からの関心である。社会心理学 に扔ける自己意識理論の発展にともなって, 自己意識 と精神病理の関係を扱う理論が多く提出されている (Ingram, 1990)。取り上げられた精神病理には, 対人 不安，抑うつ，アルコール依存などがある。妄想的思 考についても, Fenigstein \& Vanable (1992) が自己 意識との関係を調べている。彼らは，パラノイア傾向 (何でも自分と関係があるのではないかと疑う被害妄 想的な思考傾向）と，公的自己意識が関係するという 仮説をたて, 大学生を被験者とする研究から実証して いる，彼らは，妄想的観念を測定するために，パラ八 イア尺度（Paranoia Scale）を作成している。これは MMPI のなかから 20 項目を選び出したものである. 彼らは，この尺度を大学生 581 名に 5 段階評定で実施 し, 妄想的観念は健常者にもそれほど珍しいものでは ないと述べている。これまでの妄想研究は, 精神分裂 病の妄想を扱ったものが主であうたが，こうした文脈 から, 健常者の妄想的観念関心がもたれるようにな っている。

以上のように, 妄想的観念についての研究は増えて いるが，そこにはまだ多くの問題が残されている。そ のひとつとして, 妄想的観念の主題を包括的にとらえ る枠組みがないことが挙げられる。妄想的観念は，一
る. 形式的側面というのは, 前述の Jaspers（1948） の 3 特徵にみられるように, 確信度・訂正可能性・内 容の正誤といった点に関するものである。一方, 主題 的側面というのは, その内容が被害的か誇大的かとい った区別であり，これまでは精神分裂病・うつ病・躁 病に対応して, 被害・微小・誇大の三つの主題に分け られることが多い.

これまで, Jaspers（1948）をはじめ, 形式的な側 面に関しては精緻な研究が抢こなわれてきたが, 主題 的側面に関しては, 整理がついておらず構造化が不十 分である。たとえば，被害・微小・誇大の 3 分類にし ても, 微小観念と誇大観念が感情価において対称的で あるのはわかるが，それらと被害観念はどのような関 係にあるのか理解しにくい. DSM-IV の妄想的障害に おいても, 色情型・誇大型・䃚妬型・被害型・身体 型・混合型の 6 主題を単に列挙するだけで, それらの 関係については述へていない。 また，いろいろな診断 面接基準をみても, 妄想主題を羅列するのみで, それ らの関係は不明確である。

これに関連して, 前述した PQ 法や MADSのよう に, 妄想の形式的側面のアセスメントは多いのに対 し，主題的側面のアセスメント技法はほとんどない。 前述のパラノイア尺度は確かに妄想的観念の主題を測 定しているが, 被害観念だけを扱っており, それは妄 想的観念のごく一部にすぎない.

以上の上うな観点から, 本研究では, 第一に, 妄想 的観念の主題的側面を整理することを目的とした。本 研究は, Fenigstein \& Vanable (1992) のパラノイア 尺度を拡張し，その不満を克服するような自己評価の 質問紙を開発し, その結果にもとづいて妄想主題の構 造化を試みる。また, パラノイア尺度は, MMPI か ら項目を選び，健常大学生において標準化されたた め, 果たして臨床的な意義がどれだけあるか不明であ る。そこで, 第二に, 新しい尺度について, 臨床的な 妥当性を検討することを目的とした。尺度の妥当性に は内容的妥当性, 構成概念妥当性, 基準関連妥当性が ある。本研究では，まず開発された質問紙と， Fenigstein \& Vanable のパラノイア尺度の相関をみる ことにより構成概念妥当性を調べた。次に, 複数の専 門家に独立に尺度の評定を求める方法（池田, 1973） を用いて内容的妥当性を検討した。第三に，こうした 尺度を用いて, Fenigstein \& Vanable (1992) がいう ように，健常者の多くが妄想的観念を体験しているか どうかを調べた。

\section{研究 1 : 大学生調査}

\section{方 法}

質問紙の作成 妄想的観念に関する文献や診断基 準，面接基準，症状評価尺度などを参考にして，観念 
Table 1

妄想観念チェックリストの負感情項目の尺度と因子負荷量

\begin{tabular}{|c|c|c|c|c|c|c|}
\hline \multirow{2}{*}{ 尺度名と質問項目 } & \multicolumn{3}{|c|}{ 因子負荷量 } & \multicolumn{3}{|c|}{ 出現率a) $(\%)$} \\
\hline & $\mathrm{Fl}$ & $\mathrm{F} 2$ & F3 & 1 & 2 & 3 \\
\hline
\end{tabular}

$1 \mathrm{a}$ 疎外観念尺度

周りの人から疎まれたり嫌がられたりしているのではないかという疑い だれかが私を見て, ばかにしている, と感じられる体験

私のいないところで，だれかが私をけなしているのではないかという疑い

他の人から“のけもの”にされているのではないか，という疑い

他の人の話し声が, 私の悪口を言っているように聞こえた体験

周りの人はだれも信用できない, という疑い

まわりでいやなことがおこると, 私のせいだと責められているように感じら れる体験

$1 \mathrm{~b}$ 微小観念尺度

まったくひとりぼっちで居場所がない, という考え

人より容姿 (顔や体型) が劣っているのではないか, という感じ

他の人はみんなもっているのに，自分だけ何かの能力が欠けているのではな いかという考え

人より仕事や勉強の能力が低いのではないか, という考え

$\begin{array}{rrrrrr}.76 & -.09 & .10 & 16 & 63 & 21 \\ .70 & .09 & -.05 & 27 & 56 & 17 \\ .66 & .03 & .04 & 23 & 61 & 16 \\ .61 & .08 & -.11 & 19 & 60 & 21 \\ .60 & -.01 & -.04 & 25 & 57 & 18 \\ .49 & .29 & -.11 & 58 & 33 & 8 \\ & & & & & \\ .45 & .00 & .16 & 27 & 58 & 14 \\ & & & & & \\ & & & & & \\ .61 & .20 & -.17 & 49 & 38 & 13 \\ .57 & -.01 & .04 & 21 & 57 & 22 \\ & & & & & \\ .51 & .03 & .16 & 32 & 49 & 20 \\ .46 & -.05 & .23 & 21 & 54 & 25\end{array}$

2 被害観念尺度

私の考えていることが, 他の人に知られている, という感じ

私の考えていることが, 相手から読まれている, という考え

だれかが私をワナにかけようとしているのではないか, という疑い

私はだれかに利用されているのではないか，という疑い

だれかに操られているように感じられる体験。

だれかが私を陥れようとして狙っている，と感じられる体験

神様や霊などが, 私の行動を邪魔している, という感じ

3 加害観念尺度

知らない間に，他の人を侮辱しているのではないか，という疑い

知らない間に他の人の心を傷つけることを言っているのではないかという疑 w

他の人たちに迷惑をかけている，という感じ

取りかえしのつかない重い罪を犯してしまったのではないかという考え

知らない間に，だれかの人生をダメにしているのではないか，という疑い

知らない間にだれかにケガをさせているのではないか, という疑い

$\begin{array}{rrrrrr}-.07 & .65 & .03 & 48 & 46 & 6 \\ -.11 & .65 & .21 & 46 & 45 & 9 \\ .12 & .65 & -.09 & 72 & 26 & 3 \\ .04 & .52 & .25 & 69 & 28 & 4 \\ -.01 & .47 & .12 & 85 & 14 & 2 \\ .19 & .42 & -.03 & 81 & 18 & 2 \\ .13 & .40 & -.16 & 90 & 9 & 1\end{array}$

a) 出現率の 1 は“まったくない”，2 は“たまにある”，3は“よくある”を示す。

の主題や内容をあらわす記述を 100 項目以上集めた. 健常者への予備調査をおこない出現率のきわめて低い 項目を削除し, また, 精神分裂病患者への予備調査を おこない難解な項目を削除したり修正したりした。そ して，51 項目からなる質問紙を作成した。負の感情 価をもつ 30 項目と, 正の感情価をもつ 21 項目に分か れる。これを妄想観念チェックリスト (Delusional Ideation Check-List) と命名した. 以下, DICL と略 す。“全くない”，“たまにある”，“よくある”の 3 件 法で回答を求め，それぞれ $1,2,3$ と配点した。
パラノイア尺度 Fenigstein \& Vanable (1992) の パラノイア尺度 20 項目を原著者の承諾を得て翻訳し た。まず，著者の 1 名がパラノイア尺度の日本語訳を 作り，それを別の者がバックトランスレートし，それ をもとに著者の 1 名が日本語訳を調整した。“まった くあてはまらない”から“かなりあてはまる”までの 5 件法で回答を求め，1-5 と配点した。

被験者 大学 $1 \cdot 2$ 年生を対象とする教育学の授業 において，2週の間をあけて 2 回集団施行した。第 1 回目の被験者は 308 名（男 215 名, 女93名）であっ 
Table 3

妄想観念チェックリストの各尺度の統計量

\begin{tabular}{|c|c|c|c|c|c|c|c|c|}
\hline 感情 & 青 尺度名 & 項目数 & 平均 & $S D$ & 体験率a) & $\alpha$ 係数 & 再検査a) & $\mathrm{PS}^{\mathrm{a})}$ \\
\hline \multirow[t]{4}{*}{ 負 } & 1a 疎外観念 & 7 & 1.88 & .42 & $98.4 \%$ & .80 & $.69^{* *}$ & $.49^{* *}$ \\
\hline & $1 b$ 微小観念 & 4 & 1.90 & .49 & $94.2 \%$ & .68 & $.71^{* *}$ & $.39 * *$ \\
\hline & 2 被害観念 & 7 & 1.34 & .31 & $75.0 \%$ & .72 & $.49^{* *}$ & $.48^{* *}$ \\
\hline & 3 加害観念 & 6 & 1.67 & .38 & $94.2 \%$ & .73 & $.63^{* *}$ & $.32 * *$ \\
\hline \multirow[t]{4}{*}{ 正 } & 庇護観念 & 4 & 1.29 & .45 & $40.9 \%$ & .87 & $.70^{* *}$ & .07 \\
\hline & 2 自己肯定観念 & 5 & 1.40 & .41 & $69.9 \%$ & .76 & $.68^{* *}$ & .05 \\
\hline & 3 被好意観念 & 5 & 1.35 & .34 & $66.9 \%$ & .78 & $.67 * *$ & .07 \\
\hline & 4 他者操作観念 & 4 & 1.54 & .54 & $82.5 \%$ & .66 & $.64^{* *}$ & $.15^{* *}$ \\
\hline
\end{tabular}

a) “体験率”は各尺度内の 1 項目以上で“たまにある”または“よくある”と答えた 被験者の割合を示す。“再検査” は再検査信頼性を示す。“PS”はパラノイア尺度 (Fenigstein \& Vanable, 1992) との相関係数を示す.

${ }^{*} p<.05,{ }^{* *} p<.01$.

操作観念と命名した. なお, Table 2 に示すとおり, “人を思いどおりに操ったりできるという感じ”とい う項目は, 第 2 因子の負荷量が最も高く, 本来なら自 己肯定観念に含めるべきところである。しかし，この 項目が, 内容的には他者を操るという他者操作観念を あらわしていること，第 4 因子の負荷量も. 38 と高い こと, この項目を除去すると他者操作観念尺度が 3 項 目になり尺度の信頼性が下がるおそれがあることか ら，あえて他者操作観念に含めることにした。

尺度の関係 八つの尺度の内容を考えると, Figure 1 に示すように, 自己から他者に向かうもの, 他者か ら自己に向かうもの，自己完結しているものに整理で きる。

尺度の平均值と体験率 八つの尺度ごとに, 項目の 総和を項目数で割った值を尺度得点とした。各尺度の 平均值を Table 3 に示す。一般的には正感情項目より も負感情項目の頻度が高い.また, 各尺度内の 1 項目 以上で“たまにある”または“よくある”と答えた被 験者の割合を体験率として Table 3 に示す。体験率は 全般に高い值を示しており, 疎外・微小・加害などの 観念はほとんど全員が体験しているといえる，最も低 いのは庇護観念であった。
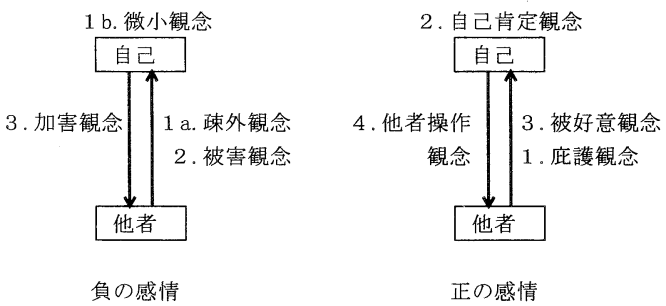

Figure 1. 妄想観念チェックリストの尺度間の関係。
尺度の信頼性 Table 3 に示すように, 各尺度の $\alpha$ 係数をみると, 微小観念と他者操作観念はやや低い が, 他は.7 以上の值を示しており, 尺度の内的一貫 性はお执むね満足できる高さである。また， 2 回の調 査で共通していた 204 名の結果について, 尺度ごとに 相関係数を求めたものを Table 3 に示す. 被害観念を 除く七つの尺度では.60以上の相関係数を示してお り, 中程度の再検査信頼性をもつことを示している。 被害観念は相関係数が. 48 と低く, 再検査信頼性は低 i.

構成概念妥当性 Table 3 に示すように, DICL と Fenigstein \& Vanable (1992) のパラノイア尺度との 相関をみると，負感情尺度については，いずれも.3 以上の有意な正の相関がみられた，正感情尺度につい てみると, 他者操作観念以外の尺度との間には相関関 係はみられなかった. 他者操作観念尺度との間には有 意な相関がみられたが低いものであった。

\section{研究 $2 ：$ 専門家調査}

\section{方 法}

対象 四つの施設に勤務する精神神経科の医師 10 名を対象とした。臨床経験は 4-40 年である.

手続き 診断的重要度と頻度予想について, 質問紙 法で回答を求めた。まず，DICLの各項目を示し， “まだ診断のついていない患者が，外来で，項目のよ うなことを体験していると訴えた場合，急性の妄想型 分裂病と診断するのにどのくらい重要だと思うか”に ついて判断を求めた。“まったく重要でない”“あまり 重要でない”“まあ重要である”“きわめて重要であ る”の 4 件法で評定を求め, それぞれ $1,2 ， 3 ， 4$ と 配点した。 また, 妄想型分裂病の診断的重要度と比較 
Table 4

精神科医による診断的重要度の評定值

\begin{tabular}{|c|c|c|c|c|c|c|c|c|}
\hline \multirow{2}{*}{ 感情 } & \multirow{2}{*}{ 尺度名 } & \multirow{2}{*}{ 項目数 } & \multicolumn{2}{|c|}{ 妄想型分裂病 } & \multicolumn{2}{|c|}{ 不安神経症 } & \multirow{2}{*}{$t$ 值 } & \multirow{2}{*}{$p$} \\
\hline & & & 平均 & $S D$ & 平均 & $S D$ & & \\
\hline \multirow[t]{4}{*}{ 負 } & 1a 疎外観念 & 7 & 3.31 & .34 & 1.83 & .42 & 6.93 & $.0001^{* *}$ \\
\hline & $1 b$ 微小観念 & 4 & 2.02 & .53 & 2.37 & .49 & 1.87 & .0942 \\
\hline & 2 被害観念 & 7 & 3.61 & .30 & 1.17 & .21 & 29.18 & $.0001^{* *}$ \\
\hline & 3 加害観念 & 6 & 2.17 & .72 & 1.83 & .51 & 1.03 & .3290 \\
\hline \multirow[t]{4}{*}{ 正 } & 1 庇護観念 & 4 & 2.65 & .65 & 1.27 & .38 & 5.20 & $.0006^{*}$ \\
\hline & 2 自己肯定観念 & 5 & 2.52 & .70 & 1.22 & .30 & 5.57 & $.0003 *$ \\
\hline & 3 被好意観念 & 5 & 2.18 & .69 & 1.18 & .30 & 4.60 & $.0013^{*}$ \\
\hline & 4 他者操作観念 & 4 & 2.25 & .75 & 1.25 & .44 & 3.91 & $.0035^{*}$ \\
\hline
\end{tabular}

注）有意水準は Bonfferoni の方法にもとづいて定めた。 ${ }^{*} p<.00625,{ }^{* *} p<.00125$.

Table 5

精神科医による頻度予想の評定值

\begin{tabular}{|c|c|c|c|c|c|c|c|c|c|c|}
\hline \multirow{2}{*}{ 感情 } & \multirow{2}{*}{ 尺度名 } & \multirow{2}{*}{ 項目数 } & \multicolumn{2}{|c|}{ 妄想型分裂病 } & \multicolumn{2}{|c|}{ 不安神経症 } & \multicolumn{2}{|c|}{ 健常大学生 } & \multirow{2}{*}{$\begin{array}{c}F \text { 值 } \\
(2,27)\end{array}$} & \multirow{2}{*}{$p$} \\
\hline & & & 平均 & $S D$ & 平均 & $S D$ & 平均 & $S D$ & & \\
\hline \multirow[t]{4}{*}{ 負 } & 1a 疎外観念 & 7 & 3.09 & .79 & 1.57 & .42 & 1.41 & .68 & 20.15 & $.0001^{* *}$ \\
\hline & $1 \mathrm{~b}$ 微小観念 & 4 & 1.72 & .48 & 2.15 & .70 & 1.72 & .56 & 1.76 & .1921 \\
\hline & 2 被害観念 & 7 & 2.74 & 1.05 & 1.01 & .05 & 1.04 & .10 & 26.64 & $.0001 * *$ \\
\hline & 3 加害観念 & 6 & 1.38 & .44 & 1.38 & .29 & 1.17 & .22 & 1.43 & .2563 \\
\hline \multirow[t]{4}{*}{ 正 } & 1 庇護観念 & 4 & 1.65 & .53 & 1.05 & .11 & 1.15 & .34 & 7.64 & $.0023^{*}$ \\
\hline & 2 自己肯定観念 & 5 & 1.62 & .58 & 1.06 & .13 & 1.34 & .54 & 3.65 & .0396 \\
\hline & 3 被好意観念 & 5 & 1.26 & .30 & 1.06 & .13 & 1.36 & .39 & 2.72 & .0836 \\
\hline & 4 他者操作観念 & 4 & 1.50 & .47 & 1.10 & .21 & 1.42 & .57 & 2.31 & .1184 \\
\hline
\end{tabular}

注）有意水準は Bonfferoni の方法にもとづいて定めた。 ${ }^{*} p<.00625,{ }^{* *} p<.00125$.

対照するため，ほとんど妄想があらわれることはない とされている神経症圏内の精神病理のうちから，ここ では妄想型分裂病の症状とあまり重複がないと考えら れる不安神経症を選び, その診断的重要度について尋 ねた。すなわち，DICLの各項目を示し，“まだ診断 のついていない患者が, 外来で, 項目のようなことを 体験していると訴えた場合，不安神経症と診断するの にどのくらい重要だと思うか”について，上と同じ 4 件法で判断を求めた。

次に, DICLの各項目を示し，“急性の妄想型分裂 病の患者に面接中に聞いた場合，それぞれの項目につ いて，体験したことがあると答える患者はどのくらい の割合だと予想されるがについて判断を求めた。ま た，比較対照のため，“不安神経症の患者に聞いた場 合，それぞれの項目について，体験したことがあると 答える患者はどのくらいの割合だと予想されるか”に ついて, さらに, “心身とも健常と思われる大学生に 聞いた場合，それぞれの項目について，体験したこと
があると答える大学生はどのくらいの割合だと予想さ れるか”について判断を求めた。 以上の頻度予想は, “0-19\%”, “20-39\%”, “40-59\%”, “60-79\%”, “80-100\%”の5 件法で評定を求め, それぞれ $1-5$ と配点した。

\section{結 果}

診断的重要度, 頻度予想ともに, 研究 1 で得られた 八つの尺度ごとに，項目の得点を合計し，項目数で割 った。 その結果を Table 4 と Table 5 に示す。

診断的重要度 Table 4 に示すように, 妄想型分裂 病についてみると，とくに被害観念と疎外観念の二つ が飛び抜けて高く，值が 3.0 を超えている，最も低い のは微小観念である. 不安神経症についてみると, Table 4 に示すように, すべての観念で 2.5 末満の值 である。八つの尺度の診断重要度について, 診断対象 （妄想型分裂病と不安神経症）を独立変数とする 1 元 配置の多変量分散分析（MANOVA）を扢こなった。 
その結果, 有意な診断の効果がみられた $(F(8,11)=$ $152.77, p=.0001)$. そこで, 各変数について, Bonfferoni の方法によって有意水準を $p<.00625$ とし て $t$ 検定をおこなった. その結果, Table 4 に示すよ うに, 疎外観念と被害観念においては $1 \%$ 水準で, 庇 護・自己肯定・被好意・他者操作の各観念においては $5 \%$ 水準で, 妄想型分裂病の重要度が不安神経症の重 要度より有意に高かった。このことは, 精神科医が妄 想型分裂病と診断するにあたって, 不安神経症と比較 して相対的に, 疎外・被害・庇護 - 自己肯定・被好 意・他者操作の六つの観念を重視していることを示し ている. なお, Ia 疎外観念と Ib 微小観念は, 研究 1 の因子分析においては同じ因子に含まれており，これ らの観念は被験者の主観からみると同じような抑うつ 的心性をあらわすと考えられる. 研究 2 においては, 疎外観念と微小観念の診断的重要度は著しく違ってお り，精神科医の診断においては，これらの観念は異な る意味をもつと考えられる。精神科医の診断という面 からみると, これら二つの観念を分けたことには意味 があったと考えられる。

頻度予想 Table 5 に示すように，妄想型分裂病に ついては, 疎外観念と被害観念が飛び抜けて高く, 2.0 を超えている。他は 1.0 末満である. 不安神経症 については，微小観念が最も高く，2.0を超えている が，他は 1.0 末満である. 健常大学生については，八 つの尺度ともに 1.0 末満である.八つの尺度の頻度予 想について, 予想対象（妄想型分裂病・不安神経症・ 健常大学生）を独立変数とする 1 元配置の多変量分散 分析（MANOVA）をおこなった。その結果，有意な 診断の効果がみられた $(F(16,40)=4.31, p=$ .0001). そこで, 各変数について, Bonfferoni の方法 によって有意水準を $p<.00625$ として分散分析を抢こ なった。その結果, Table 5 に示すように, 疎外・被 害・庇護の各観念が有意であった。さらに, 疎外・被 害・庇護の各観念において， $\alpha$ を $p<.00625$ に保って LSD 法の多重比較を抢こなったところ，いずれの観 念においても，妄想型分裂病が，不安神経症と健常大 学生よりも有意に值が高かった。このことから，疎 外・被害・庇護の各観念に扔いて, 精神科医は不安神 経症や健常大学生よりも妄想型分裂病で頻度が高いと 予想しているといえる。

次に, 健常大学生についての頻度予想と, 研究 1 の 大学生調査に扔ける実際の值を比べた。大学生調査に おいて, 各項目ごとの出現率をみて, “たまにある” または“よくある”と答えた被験者の割合が 0-19\% ならば 1，20-39\%ならば 2, 40-59\%ならば3, 60-79\%ならば4，80-100\%ならば5と配点した。 そして, 尺度ごとに平均值を求めた。その結果, 疎外 観念 4.14 , 微小観念 3.75 , 被害観念 1.86 , 加害観念 3.33 , 庇護観念 1.75 , 自己肯定観念 2.00 , 被好意観念
2.00, 他者操作観念 3.00 であった. 大学生調査の Table 3 と比較すると, 実際の頻度は, 頻度予想より もかなり高い. とくに疎外・微小・加害の各観念につ いては差が大きい.つまり，精神科医はこれらの観念 の健常大学生の頻度を実際より過小に予想している。

\section{総合的考察}

本研究の第一の目的は，新たな質問紙を開発し，妄 想主題の構造化を試みることであった. Fenigstein \& Vanable (1992) の研究は，パラノイア尺度を開発 し, 健常大学生の多くが妄想的観念を体験しているこ とを明らかにした点では大きな意義がある。しかし， パラノイア尺度は，以下に述べるような三つの点にお いて中途半端なものであるため，健常者の妄想的観念 についての実態の解明が十分とはいえなかった。今回 作成した妄想観念チェックリスト（DICL）はこうし た不備を補うことができたといえるだろう。

第一に, Fenigstein \& Vanableのパラノイア尺度 は，妄想的観念のごく一部（被害と疎外）しか扱って おらず，診断に重要な正感情の観念が抜けている。 こ れに対し，DICL は広範囲の観念を扱っており，その 全体像を視野に入れることができる.

第二に，パラノイア尺度は妄想的観念の構造化が不 十分であった. 今回, DICL の因子分析の結果から， Figure 1 に示すように, 自己と他者の方向性と感情 価の正負によって, 妄想的観念を構造的に整理するこ とができた。特に，誇大妄想については，これまで構 造化が不十分であったが，今回の分析から，四つの観 念群に分けられることが示唆された。

第三に，パラノイア尺度は臨床的な妥当性が明確で なかった。これに対し，DICL は六つの尺度が妄想型 分裂病の診断に重要であると精神科医から評価され た。

本研究の第二の目的は, DICL の臨床的な妥当性を 調べることであった．構成概念妥当性を調べるため,

DICLとパラノイア尺度 (Fenigstein \& Vanable, 1992）の相関を調べたところ，負感情項目との間に有 意な正の相関がみられた。また，複数の精神科医に評 定を求めて内容的妥当性を検討したところ， DICLの 六つの尺度が妄想型分裂病の診断に重要であると評価 された。そのうち，疎外観念と被害観念はとくに重要 である、なお，基準関連妥当性を調べるために，著者 らは，妄想をもつ精神分裂病患者と健常者を対象とし てこの尺度を実施し比較した (未発表)。その結果， 八つの尺度のうち, 被害観念, 加害観念, 庇護観念, 他者操作観念については，患者群のほうが健常者群よ り有意に高く，基準関連妥当性が示された。

本研究の第三の目的は，新しい尺度を用いて， Fenigstein \& Vanable（1992）がいうように，健常者 の多くが妄想的観念を体験しているかどうかを確認す 
ることにあった。その結果，パラノイア尺度より包括 性と診断的有用性の高い DICL を用いて, 健常大学 生の多くが妄想と同じ内容の観念を体験していること が明らかになった。とくに，疎外・微小・加害などの 観念はほとんど全員が体験していた。

健常大学生の妄想的観念の体験頻度は，精神科医が 予想する以上に高かった。 その解釈の一つとしては, 項目に対する受け取り方が, 精神科医と健常大学生と で異なることが考えられる。これまで健常者における 分裂病類似の症状の実態を調べた研究は少なく, その 解明は，臨床診断においても有用な情報となろう。

本研究は主観的側面の整理を目的としているので, 確信度の強さや判断の正誤などの形式的側面にはふれ ていない. DICLで取り上げた観念は，必ずしも妄想 的とはいえないものも含まれている。たと光ば，健常 者の自己肯定観念などは，実際には正しい判断である 可能性もある。なんの根拠もなく自己肯定観念が強い 場合に病的な妄想的観念（誇大観念）と呼ばれるわけ である、観念が妄想であるかを考えるためには，形式 的な側面のアセスメントが必要になる。これについて は今後調べていきたい。

\section{引用文献}

American Psychiatric Association 1994 Diagnostic and statistical manual of mental disorders. 4th Ed. Washington, DC: APA.

Bentall, R. P. 1990 The syndromes and symptoms of psychosis. In R. P. Bentall (Ed.), Reconstructing schizophrenia. London: Routledge.

Brett-Jones, J., Garety, P., \& Hemsley, D. 1987 Measuring delusional experiences: A method and its application. British Journal of Clinical Psychology, 26, 257-265.

Chadwick, P., Birchwood, M., \& Trower, P. 1996 Cognitive therapy for delusions, voices and paranoia. New York: John Wiley \& Sons.

Crow, T. J. 1980 Molecular pathology of schizophrenia: More than one disease process? British Medical Journal, 280, 66-68.

Fenigstein A., \& Vanable P. 1992 Paranoia and self-consciousness. Journal of Personality and Social Psychology, 62, 12-138.

Hemsley, D., \& Garety, P. 1986 The formation of maintenance of delusions: A Bayesian analysis. British Journal of Psychiatry, 149, 51-56.

池田 央 1973 心理学研究法 第 8 巻テスト II 東 京大学出版会

Ingram, R. 1990 Self-focused attention in clinical disorders: Review and a conceptual model. Psychological Bulletin, 107, 156-176.

ヤスパース K. 内村祐之・西丸四方・島崎敏樹 - 岡 田敬蔵(訳) 1953 精神病理学總論 岩波書店

(Jaspers, K. 1948 Allgemeine Psychopathologie. 5. Auflage.)

笠原 嘉・藤縄 昭 1978 妄想 現代精神医学大系 $3 \mathrm{~A}$ 精神症状学 I 中山書店

Manschreck, T. C. 1979 The assessment of paranoid features. Comprehensive Psychiatry, 20, 370-377.

Sharp, H. M., Fear, C. F., Williams, J. M. G., Healy, D., Lowe, C. F., Yeadon, H., \& Holden, R. 1996 Delusional phenomenology: Dimensions of change. Behaviour Research and Therapy, 34, 123-142.

Strauss, J. 1969 Hallucinations and delusions as points on continua function. Archives of General Psychiatry, 21, 581-586. 